\title{
KEPUASAN KERJA MEMEDIASI PENGARUH KEPEMIMPINAN TRANSFORMASIONAL TERHADAP KOMITMEN ORGANISASIONAL KUTABEX BEACH FRONT HOTEL BALI
}

\author{
Ni Luh Sintya Yulianingsih ${ }^{1}$ \\ Agoes Ganesha Rahyuda ${ }^{2}$ \\ ${ }^{1,2}$ Fakultas Ekonomi dan Bisnis Universitas Udayana (Unud), Bali, Indonesia \\ email: sintyayulia20@gmail.com
}

\begin{abstract}
ABSTRAK
Komitmen organisasional merupakan sikap yang menunjukan loyalitas karyawan dan merupakan proses berkelanjutan bagaimana seorang anggota organisasi mengekspresikan perhatian mereka kepada kesuksesan organisasi. Tujuan dari penelitian ini adalah untuk menganalisis peran kepuasan kerja dalam memediasi pengaruh kepemimpinan transformasional terhadap komitmen organisasional karyawan KutaBex Beach Front Hotel Bali. Jumlah populasi adalah 113 orang dan sampel yang digunakan dalam penelitian ini yaitu 54 orang menggunakan rumus slovin dengan metode proportionate random sampling. Data dianalisis menggunakan teknik analisis jalur. Pengumpulan data melalui wawancara dan penyebaran kuesioner. Hasil penelitian menunjukan bahwa kepemimpinan transformasional berpengaruh positif dan signifikan terhadap kepuasan kerja dan komitmen organisasional. Selain itu kepuasan kerja berpengaruh positif dan signifikan terhadap komitmen organisasional dan kepuasan kerja memediasi pengaruh kepemimpinan transformasional terhadap komitmen organisasional secara parsial. Implikasi dari penelitian ini adalah kepuasan kerja yang tinggi dimiliki karyawan akan meningkatkan komitmen organisasi karyawan melalui pengaruh kepemimpinan transformasional.
\end{abstract}

Kata kunci : kepemimpinan transformasional, kepuasan kerja, komitmen organisasional

\begin{abstract}
Organizational commitment is an attitude that shows employee loyalty and ongoing process of how they expresses their attention to organization's success. Purpose of study is to analyze the role of job satisfaction in mediating effect of transformational leadership on organizational commitment of KutaBex Beach Front Hotel Bali employees. The population was 113 people and the sample are 54 people using proportionate random sampling method. Data are analyzed using path analysis techniques. Data collection through interviews and questionnaires. The results showed that transformational leadership had a positive and significant effect on job satisfaction and organizational commitment. In addition, job satisfaction has a positive and significant effect on organizational commitment and job satisfaction mediates the effect of transformational leadership on organizational commitment partially. The implication of this research is that high job satisfaction owned by employees will increase employee organizational commitment through the influence of transformational leadership.
\end{abstract}

Keywords: transformational leadership, job satisfaction, organizational commitment 


\section{PENDAHULUAN}

Pariwisata merupakan salah satu industri yang mengalami pertumbuhan cepat di di Indonesia. Bali merupakan salah satu destinasi tujuan pariwisata yang ada di Indonesia.Berbagai budaya dan keindahan alamnya menarik wisatawan mancanegara maupun domestik untuk datang berkunjung ke pulau Bali. Hal ini dapat dilihat dari jumlah wisatawan mancanegara yang berkunjung ke Bali selalu meningkat dari tahun ke tahunnya. Tabel 1. menjelaskan bahwa terjadi perkembangan industri pariwisata dimana kunjungan wisatawan asing yang berkunjung ke Bali mengalami peningkatan.

Tabel 1.

Jumlah Wisatawan Asing ke Bali Tahun 2014 - 2018

\begin{tabular}{ccc}
\hline Tahun & Total & Pertumbuhan (\%) \\
\hline 2014 & 3.766 .638 & 14,89 \\
2015 & 4.001 .835 & 6,24 \\
2016 & 4.927 .937 & 23,14 \\
2017 & 5.697 .739 & 15,62 \\
2018 & 6.070 .473 & 6,54 \\
\hline
\end{tabular}

Sumber : Data diolah, 2019

Tabel 1. mengindikasikan bahwa pada lima tahun terakhir telah terjadi peningkatan jumlah wisatawan asing yang berkunjung ke Bali lebih dari 5 persen setiap tahunnya. Hal ini menjadi bukti bahwa Bali merupakan salah satu tujuan wisata wisatawan asing. Meningkatnya perkembangan pariwisata menyebabkan bisnis perhotelan membutuhkan peningkatan karyawan yang berkompeten. Setiap perusahaan harus memperhatikan kinerja sumber daya manusianya yaitu karyawan agar mampu mewujudkan tujuan yang telah ditetapkan. Memperhatikan dan mengelola sumber daya manusia dalam suatu perusahaan sangatlah penting. Perusahaan akan selalu dituntut untuk meningkatkan kualitas sumber dayanya. Pertumbuhan bisnis pariwisata ini menyebabkan tingkat kebutuhan sumber daya manusia semakin tinggi. Sumber daya dalam suatu perusahaan menentukan keefektifan berjalannya kegiatan dalam suatu perusahaan tersebut. Komitmen karyawan merupakan satu faktor penting dalam rencana jangka panjang perusahaan. Putra \& Wibawa (2015) mengatakan bahwa komitmen organisasi adalah hal yang berharga untuk seluruh organisasi, dan bukan hanya untuk pekerjaan, maupun kelompok kerja.

KutaBex Beach Front Hotel, Bali merupakan salah satu industri perhotelan yang pada awalnya KutaBex adalah sebagai pusat pembelanjaan yang sangat ramai pengunjung. Pada tahun 2014 owner melihat peluang bisnis yang lebih menjanjikan, sehingga dari pihak owner memutuskan mengalih fungsikan propertinya, maka dialihkan Kutabex Mall menjadi Hotel dan diberi nama KutaBex Beach Front Hotel. Berdasarkan data yang didapat dari hasil wawancara 
dengan pihak Human Resource Development, dapat dilihat bahwa di KutaBex Beach Front Hotel terjadi masalah dalam komitmen karyawan, dimana terdapat 11 karyawan yang mengundurkan diri atau resign pada tahun 2018. Hal ini mengindikasikan rendahnya komitmen karyawan pada KutaBex Beach Front Hotel. Dari hasil wawancara didapat bahwa karyawan yang resign dengan alasan yang disebabkan karena ketidakpuasan karyawan terhadap pekerjaan dan jabatan yang mereka dapatkan tidak sesuai keinginan mereka. Dalam perusahaan ini karyawan tidak dengan mudah menduduki jabatan yang mereka inginkan namun dengan proses dan pencapaian yang harus mereka lewati terlebih dahulu, dan juga terjadi ketidaksesuaian upah dengan pekerjaan yang mereka dapatkan diperusahaan.

Berdasarkan hasil wawancara selain masalah komitmen karyawan, terdapat masalah lain yang dihadapi oleh KutaBex Beach Front Hotel Bali adalah kurangnya partisipasi karyawan terhadap perusahaan dalam kegiatan yang diadakan oleh perusahaan. Beberapa karyawan tidak mau ikut menghadiri kegiatan tersebut seperti contohnya yaitu general training (internal dari supervisor, eksternal dari pihak BPJS) yang diberikan sebulan sekali dan kegiatan olahraga berupa futsal seminggu sekali, badminton seminggu dua kali, dan zumba sebulan sekali. Hal ini dapat terjadi disebabkan oleh kurangnya rasa saling memiliki antar karyawan, kurangnya rasa kekeluargaan yang dimiliki oleh masing-masing karyawan dan kurangnya rasa keperdulian terhadap perusahaan. Karyawan kurang memiliki rasa keterikatan dan rasa memiliki terhadap perusahaan, terdapat karyawan KutaBex Beach Front Hotel yang tidak mengikuti peraturan yang ditentukan oleh perusahaan seperti seringnya keterlambatan atas kehadiran karyawan.

Upaya dalam meningkatkan komitmen organisasi para karyawan, tidak lepas dari gaya kepemimpinan yang diterapkan, dimana arti dari kepemimpinan adalah upaya seseorang dalam mempengaruhi orang lain agar bertindak sesuai dengan yang diinginkan olehnya. Dorongan dan arahan yang diberikan seorang pemimpin atau atasan sangat mempengaruhi tinggi rendahnya komitmen karyawan pada perusahaan KutaBex Beach Front Hotel tersebut. Masalah komitmen organisasi ini terjadi didorong oleh masalah mengenai kepuasan kerja pada karyawan KutaBex Beach Front Hotel, setelah melakukan wawancara dengan dua orang karyawan yang telah resign dari perusahaan. Hal itu terjadi disebabkan karena rendahnya dorongan dari pemimpin atau atasan yang diberikan perusahaan kepada karyawan.

Kepemimpinan transformasional adalah suatu model kepemimpinan untuk meningkatkan sumberdaya manusia dengan dan hubungan efek pemimpin terhadap bawahan (Chan \& Mak, 2015). Penelitian yang dilakukan Widjaja et al. (2016) menemukan hasil bahwa kepemimpinan transformasional berpengaruh positif terhadap komitmen organisasional. Njoroge et al. (2015) juga menyatakan bahwa terdapat pengaruh positif dan signifikan antara kepemimpinan transformasional terhadap komitmen organisasional. Kepemimpinan 
transformasional juga dapat berpengaruh terhadap kepuasan kerja, jika pemimpin atau atasan karyawan memberikan motivasi atau dorongan dalam bekerja terhadap karyawan terlebih dengan karyawan yang berprestasi di perusahaan tersebut serta atasan memperhatikan hal itu dan memberikan feedback kepada karyawan atas kinerja yang telah mereka kerjakan dengan baik, maka akan timbul rasa kepuasan tersendiri pada perusahaan tersebut.

Berdasarkan uraian diatas dapat dilihat bahwa kepemimpinan transformasional dapat mempengaruhi kepuasan kerja, jika semakin tinggi karyawan mendapatkan dorongan dari pimpinan atau atasannya maka akan semakin tinggi pula kepuasan yang dirasakan oleh seorang karyawan. Kepuasan kerja juga dapat mepengaruhi komitmen organisasional, jika karyawan merasa puas akan feedback yang diberikan oleh perusahaan atas kinerjanya maka semakin tinggi komitmen karyawan terhadap perusahaan. Tingkat kepuasan kerja mampu meningkatkan komitmen organisasi, karena semakin tinggi kepuasan kerja yang dirasakan oleh karyawan, maka semakin termotivasi pula karyawan dalam meningkatkan komitmennya bekerja dan begitu pula sebaliknya. Manajer perusahaan haruslah memberi kepastian bahwasannya pegawai mempunyai tingkat kepuasan kerja yang besar dalam rangka agar memberi peningkatan tingkat komitmen pegawai.

Karakus et al. (2015) mendapatkan hasil pada kepuasan kerja mempunyai pengaruh positif serta signifikan pada komitmen organisasional. Shurbagi (2015) mendapatkan hasil bahwasannya kepuasan kerja mempunyai pengaruh positif juga signifikan terhadap komitmen organisasional. Babalola (2016) menemukan bahwa dimensi kepemimpinan transformasional memiliki pengaruh yang signifikan terhadap kepuasan kerja dan komitmen organisasional. Gulluce et al. (2016) menyatakan bahwa gaya kepemimpinan transformasional secara signifikan berkorelasi dengan komitmen organisasional. Kepuasan kerja mampu menjadi mediasi antara kepemimpinan transformasional terhadap komitmen organisasional, hal ini didukung oleh penelitan Bhaskara \& Subudi (2019)

Berdasarkan rumusan masalah tersebut, maka tujuan dari penelitian ini adalah sebagai berikut:1)Untuk menjelaskan pengaruh kepemimpinan transformasional terhadap kepuasan kerja pada KutaBex Beach Front Hotel, Bali. 2)Untuk menjelaskan pengaruh kepemimpinan transformasional terhadap komitmen organisasional pada KutaBex Beach Front Hotel, Bali.3)Untuk pengaruh kepuasan kerja terhadap komitmen organisasional KutaBex Beach Front Hotel, Bali. 4)Untuk menjelaskan peran kepuasan kerja dalam memediasi pengaruh kepemimpinan transformasional terhadap komitmen organisasional KutaBex Beach Front Hotel, Bali.

Teori yang menjadi acuan dalam penelitian ini yaitu Teori Pertukaran Sosial (Social Exchange Theory). Teori Pertukaran Sosial adalah pandangan karyawan ketika mereka diperlakukan dengan baik oleh organisasi, maka 
karyawan akan cenderung melakukan balas budi dengan berperilaku dan berpartisipasi lebih terhadap organisasi (Mighfar, 2015). Babalola (2016) menyebutkan kinerja pengawas dalam hal kepemimpinan transformasional dapat memiliki dampak signifikan positif pada bawahan tingkat kepuasan kerja.

Athanasios \& Belias (2015) juga mengatakan bahwa kepemimpinan transformasional berpengaruh positif terhadap kepuasan kerja. Idrus et al. (2016) menyatakan ada hubungan yang positif dan signifikan antara gaya kepemimpinan transformasional terhadap kepuasann kerja karyawan. Li et al. (2019) mengatakan bahwa organisasi perlu memiliki pemimpin tipe transformasional untuk memberikan tim yang efektif dalam bekerja untuk meningkatkan kepuasan kerja. Penelitian Eliyana et al. (2019) menyimpulkan bahwa kepemimpinan transformasional secara parsial merupakan variabel yang mampu meningkatkan kepuasan. Berdasarkan berbagai hasil penelitian tersebut dapat dikemukakan hipotesis sebagai berikut:

$\mathrm{H}_{1}$ : Kepemimpinan transformasional berpengaruh positif dan signifikan terhadap kepuasan kerja.

Kepemimpinan transformasional cenderung meningkatkan harga diri dan nilai kerja pengikut dengan menjadi anggota dari pemimpin dimana pengikut menerima dukungan yang lebih baik dan bangga menjadi anggota dari pemimpin sehingga dapat meningkatkan komitmen mereka terhadap organisasi. Penelitian yang dilakukan Widjaja et al. (2016) menemukan hasil bahwa kepemimpinan transformasional berpengaruh positif terhadap komitmen organisasional. Gulluce et al. (2016) menyatakan bahwa gaya kepemimpinan transformasional secara signifikan berkorelasi dengan komitmen organisasional.

Hal tersebut juga sejalan dengan hasil penelitian yang dilakukan oleh Tjahjono et al. (2018), Njoroge et al. (2015) terdapat pengaruh signifikan antara kepemimpinan transformasional terhadap komitmen organisasional. Supit (2016) dan Jain \& Duggal (2016) menemukan bahwa kepemimpinan transformasional berpengaruh positif terhadap komitmen organisasional karyawan. Berdasarkan berbagai hasil penelitian tersebut dapat dikemukakan hipotesis sebagai berikut: $\mathrm{H}_{2}$ : Kepemimpinan transformasional berpengaruh positif dan signifikan terhadap komitmen organisasional.

Kepuasan kerja merupakan hal penting yang dimiliki individu di dalam bekerja, dimana setiap individu pekerja memiliki karakteristik yang berbeda beda, maka tingkat kepuasan kerjanya pun berbeda - beda pula. Shah et al. (2015) menyatakan bahwa terdapat pengaruh positif antara kepuasan kerja terhadap komitmen organisasional karyawan. Imam et al. (2015) menyatakan bahwa terdapat pengaruh positif antara kepuasan kerja terhadap komitmen organisasional karyawan

Wardhani et al. (2015) menyatakan bahwa kepuasan kerja berpengaruh signifikan terhadap komitmen organisasional karyawan. Tentama \& Pranungsari (2016) menyatakan bahwa terdapat pengaruh positif antara kepuasan kerja guru terhadap komitmen organisasional. Karakus et al. (2015) dan Shurbagi (2015) mendapatkan hasil bahwasannya kepuasan kerja mempunyai pengaruh positif juga signifikan terhadap komitmen organisasional.Berdasarkan penjelasan diatas, maka hipotesis yang dapat disusun sebagai berikut : 
$\mathrm{H}_{3}$ : Kepuasan kerja berpengaruh positif dan signifikan terhadap komitmen organisasional.

Berdasarkan penelitian yang dilakukan oleh Akbar et al. (2016) meneliti hubungan antara variabel kepuasan kerja dan komitmen organisasional, yang membuktikan bahwa kepuasan kerja memiliki hubungan yang signifikan dan positif terhadap tiga dimensi komitmen organisasional, yaitu komitmen afektif, komitmen berkelanjutan, dan komitmen normatif. Hubungan positif moderat signifikan juga ditemukan antara aspek kepuasan kerja, faktor demografi, dan komitmen organisasional.

Suryaningsih et al. (2017) menemukan fakta bahwa indikator kepemimpinan transformasional yang meliputi artikulasi visi, dan stimulasi intelektual adalah prediktor yang signifikan untuk komitmen organisasional. Melalui dukungan individual, pemimpin transformasional menghormati pengikut mereka dan memahami perasaan dan kebutuhan pribadi, sehingga pengikut akan lebih terlibat dan setia. Zulkarnaen \& Sudarma (2018) yang menyatakan bahwa kepemimpinan yang bergaya transformasional memiliki pengaruh positif terhadap kepuasan kerja pegawai. Kesuma \& Supartha (2016) menyatakan bahwa kepuasan kerja memediasi kepemimpinan trasfomasional terhadap komitmen organisasional. Berdasarkan penelitian sebelumnya maka dapat diambil hipotesis sebagai berikut :

$\mathrm{H}_{4}$ :Kepuasan kerja memediasi pengaruh kepemimpinan transformasional terhadap komitmen organisasional.

Berdasarkan uraian tersebut dapat dinyatakan kerangka konseptual pada Gambar 1. berikut:

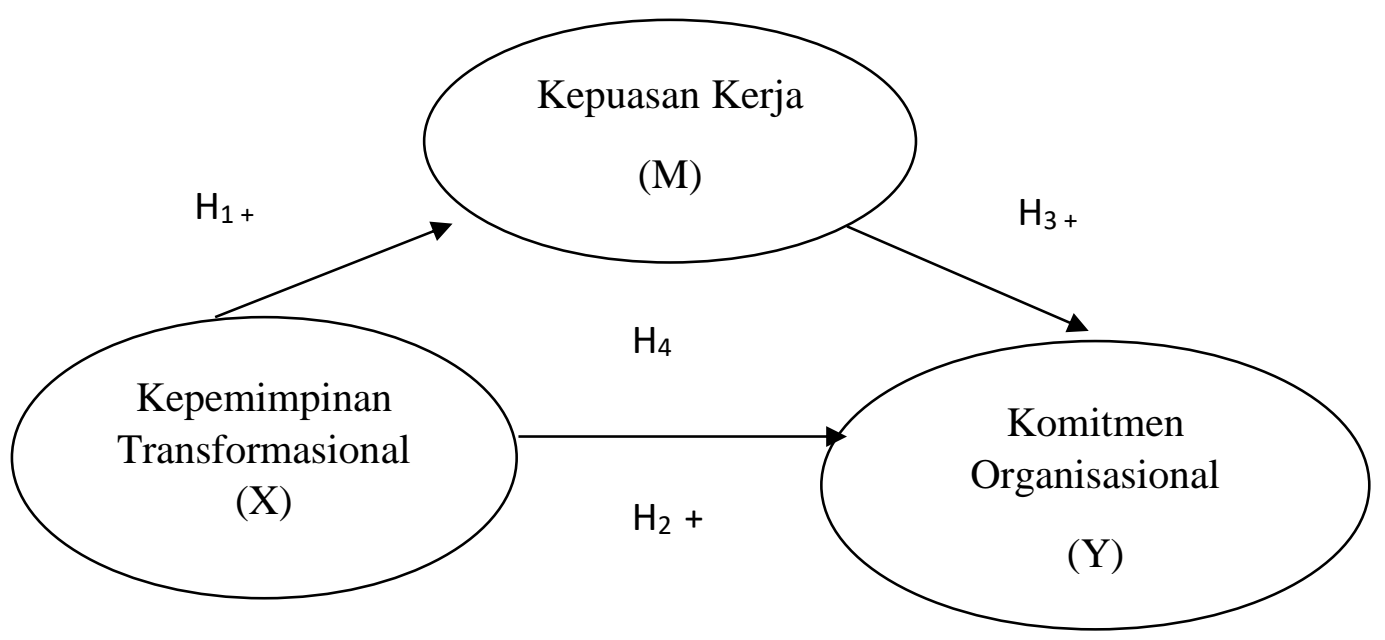

Gambar 1. Kerangka Konseptual Penelitian

\section{METODE PENELITIAN}


Penelitian ini dilakukan dengan menggunakan metode penelitian kuantitatif. Lokasi penelitian dilakukan di KutaBex Beach Front Hotel, Jl Pantai Kuta, Banjar Pande Mas, Kuta, Kabupaten Badung, Bali. Obyek dalam penelitian ini adalah kepemimpinan transformasional komitmen organisasional dan variabel kepuasan kerja sebagai mediasi pada karyawan di KutaBex Beach Front Hotel, Bali. Variabel endogen dalam penelitian ini adalah komitmen organisasional (Y). Variabel mediasi dalam penelitian ini adalah kepuasan kerja (M). Variabel eksogen dalam penelitian ini adalah Kepemimpinan transformasional (X).

Dalam penelitian ini komitmen organisasional yang dimaksud adalah adalah tingkat seorang karyawan mengidentifikasi sebuah organisasi, tujuan dan harapannya untuk tetap menjadi anggota dalam organisasi tersebut. Kepemimpinan transformasional yang dimaksud adalah adalah kepemimpinan yang dapat menginspirasi para bawahan atau pengikut untuk melampaui kepentingan diri sendiri demi kepentingan perusahaan. Kepuasan kerja yang dimaksud adalah suatu perasaan positif tentang pekerjaan seseorang yang merupakan hasil dari sebuah evaluasi karakteristiknya.

Data kuantitatif dalam penelitian berupa pendapat dari responden yang meliputi variabel bebas dan terikat. Sumber primer merupakan karyawan yang diwawancarai dan responden yaitu karyawan KutaBex Beach Front Hotel Bali yang mengisi kuisioner yang dibagikan. Sumber sekunder merupakan pihak dari perusahaan atau hotel yang memberikan data karyawan yang sudah tersedia di KutaBex Beach Front Hotel Bali, contohnya seperti sejarah berdirinya organisasi, data organisasi, struktur organisasi dan data karyawan yang resign.

Populasi dari penelitian ini adalah seluruh karyawan di KutaBex Beach Front Hotel yang berjumlah 113 karyawan. jumlah sampel KutaBex Beach Front Hotel yang akan diambil dalam penelitian ini yaitu sebanyak 54 sampel menggunakan rumus slovin dengan metode proportionate random sampling. Untuk memperoleh data, penelitian menggunakan teknik pengumpulan data dengan menggunakan metode wawancara dan kuesioner.

\section{HASIL DAN PEMBAHASAN}

KutaBex adalah nama sebuah pusat perbelanjaan (mall) yang beralamat di Jalan Pantai Kuta, Banjar Pande Mas, Bali. Pada awalnya KutaBex adalah sebuah pusat perbelanjaan yang sangat ramai pengunjung. Namun pada tahun 2014 , owner melihat peluang bisnis yang lebih menjanjikan, sehingga pihak owner memutuskan untuk mengalih fungsikan propertinya. Dengan lokasi yang sangat strategis, berada didepan pantai Kuta dan daerah pariwisata, maka dialihkanlah KutaBex Mall menjadi hotel, yang diberi nama KutaBex Beach Front Hotel Bali.

Pada bulan juli 2014, KutaBex Beach Front Hotel Bali resmi dibuka, dengan jumlah kamar yang siap dijual sebanyak 43 kamar, dalam satu lantai. Dan bulan desember 2014, kamar yang siap dijual menjadi 94 kamar dengan dua lantai. Pada awal dibuka, selain kamar tamu, KutaBex Beach Front Hotel Bali juga memiliki ruangan meeting, restaurant, dan pelayanan massage atau spa. Total kamar yang dimiliki KutaBex Beach Front Hotel Bali adalah 108 kamar tamu, 1 
ruang meeting besar atau ballroom yang berkapasitas lebih dari 400 orang dan 2 outlet restaurant yaitu KutaBex bar dan The Seven Rooftop Bar. Pada setiap kamar dilengkapi dengan penyejuk ruangan, telephone, televisi, alat pembuat kopi atau teh, kulkas kecil, pengering rambut, kotak barang berharga atau safety deposit box serta kamar mandi dengan fasilitas air panas dan dingin. Responden penelitian diambil dari karyawan pada KutaBex Beach Front Hotel Bali tahun 2019 sebanyak 54 karyawan. Data karakteristik responden adalah data responden yang dikumpulkan untuk mengetahui profil responden penelitian.

Berdasarkan hasil penelitian yang dilakukan terhadap karyawan Pada KutaBex Beach Front Hotel, Bali dapat diketahui karakteristik respondennya meliputi jenis kelamin, usia dan pendidikan terakhir yang dijelaskan pada Tabel 2. berikut:

Tabel 2.

Karakteristik Responden

\begin{tabular}{ccccc}
\hline No & Variabel & Klasifikasi & $\begin{array}{c}\text { Jumlah } \\
\text { (orang) }\end{array}$ & $\begin{array}{c}\text { Persentase } \\
(\%)\end{array}$ \\
\hline \multirow{2}{*}{1} & Jenis & Laki - Laki & 37 & 68.52 \\
& Kelamin & Perempuan & 17 & 31.48 \\
& & Jumlah & 54 & 100 \\
2 & \multirow{2}{*}{ Usia } & 17-20 Tahun & 18 & 33.33 \\
& & 21-30 Tahun & 26 & 48.15 \\
& & >30 Tahun & 10 & 18.52 \\
& \multirow{3}{*}{3} & Jumlah & 54 & 100 \\
& Pendidikan & SMA & 4 & 7.41 \\
& terakhir & Diploma & 29 & 53.70 \\
& & S1 & 21 & 38.89 \\
& & Jumlah & 54 & 100 \\
\hline
\end{tabular}

Sumber : Data diolah, 2019

Berdasarkan Tabel 2. responden dengan jenis kelamin pria yakni 37 orang atau 68,52 persen lebih mendominasi dibandingkan dengan responden dengan jenis kelamin wanita yakni 17 orang atau 31,48 persen. Hal ini berarti bahwa KutaBex Beach Front Hotel Bali lebih memerlukan banyak tenaga laki-laki karena pekerjaannya yang lebih berat, seperti Security, Engineering, Kitchen, Housekeeping.

Responden dengan usia 21 - 30 Tahun paling mendominasi diantara yang lainnya yakni 26 responden atau 48,15 persen. Sedangkan usia yang jumlahnya paling rendah yakni responden dengan usia $>30$. Tahun yakni 10 responden atau 18,52 persen. Hal ini berarti bahwa karyawan KutaBex Beach Front Hotel Bali ratarata berumur 21-30 yang merupakan usia produktif serta kreatif dalam bekerja.

Responden dengan pendidikan trakhir Diploma paling mendominasi yakni 29 orang atau 53,70 persen. Sedangkan responden yang paling sedikit yakni responden dengan pendidikan terakhir SMA yakni 4 responden atau 7,41 persen. Hal ini berarti bahwa lulusan Diploma merupakan lulusan yang telah memiliki 
keterampilan dan langsung menjurus ke dunia perhotelan, serta pariwisata biasanya membutuhkan karyawan lulusan pariwisata sesuai dengan bidang yang dibutuhkan perusahaan.

Pengujian reliabilitas adalah suatu pengujian pada instrumen penelitian demi mendapatkan hasil bahwa instrumen yang digunakan dapat dipercaya dan diandalkan Hasil penelitian uji reliabilitas dapat dilihat pada Tabel 3 berikut:

Tabel 3.

Uji Reliabilitas

\begin{tabular}{llc}
\hline No. & \multicolumn{1}{c}{ Variabel } & Cronbach's Alpha \\
\hline 1. & Kepemimpinan Transformasional (X) & 0,965 \\
2. & Kepuasan kerja (M) & 0,938 \\
3. & Komitmen organisasi $(\mathrm{Y})$ & 0,950 \\
\hline Sumber & Data diolah 2019
\end{tabular}

Masing -masing variabel berada pada titik diatas 0,60 yang ditunjukkan pada hasil Cronbach's Alpha, maka dapat dikatakan seluruh instrumen telah memenuhi syarat reliabilitas atau kehandalan sehingga dapat digunakan untuk melakukan penelitian.

Tabel 4.

Hasil Uji Validitas Instrumen Penelitian

\begin{tabular}{cccc}
\hline Variabel & Instrumen & $\begin{array}{c}\text { Pearson } \\
\text { Correlation }\end{array}$ & Sig.(tailed) \\
& X1 & 0,907 & 0,000 \\
Kepemimpinan Transformasional $(\mathrm{X})$ & X2 & 0,936 & 0,000 \\
& X3 & 0,957 & 0,000 \\
& X4 & 0,906 & 0,000 \\
& X5 & 0,936 & 0,000 \\
& X6 & 0,903 & 0,000 \\
& M1 & 0,880 & 0,000 \\
Kepuasan kerja (M) & M2 & 0,897 & 0,000 \\
& M3 & 0,934 & 0,000 \\
& M4 & 0,823 & 0,000 \\
& M5 & 0,945 & 0,000 \\
& Y1 & 0,889 & 0,000 \\
& Y2 & 0,874 & 0,000 \\
& Y3 & 0,933 & 0,000 \\
& Y4 & 0,874 & 0,000 \\
& Y5 & 0,840 & 0,000 \\
& Y6 & 0,811 & 0,000 \\
& Y7 & 0,865 & 0,000 \\
& Y8 & 0,808 & 0,000
\end{tabular}

Sumber : Data diolah, 2019 
Uji validitas dilakukan dengan mengkorelasikan antara skor faktor dengan skor total dan bila korelasi tiap faktor tersebut bernilai positif $(r>0,3)$, maka instrumen penelitian tersebut dapat dikatakan valid. Instrumen yang valid adalah instrumen yang dapat digunakan untuk mengukur apa yang seharusnya diukur. Hasil uji validitas penelitian ini ditunjukkan dalam Tabel 4. Seluruh instrumen variabel penelitian telah memenuhi syarat uji validitas yang dimana nilai skor total Pearson Correlation masing-masing instrumen berada diatas atau $>0,30$ dan mimiliki nilai signifikansi yang lebih kecil dari 5 persen $(0,05)$, maka instrumen layak digunakan menjadi alat ukur variabel-variabel tersebut.

Tabel 5.

Deskripsi Jawaban Responden terhadap Komitmen organisasional

\begin{tabular}{|c|c|c|c|c|c|c|c|c|c|}
\hline \multirow[t]{2}{*}{ No } & \multirow[t]{2}{*}{ Pernyataan } & \multicolumn{5}{|c|}{$\begin{array}{c}\text { Proporsi Jawaban } \\
\text { Responden } \\
\text { (orang) }\end{array}$} & \multirow[t]{2}{*}{ Jumlah } & \multirow[t]{2}{*}{$\begin{array}{l}\text { Rata- } \\
\text { rata }\end{array}$} & \multirow[t]{2}{*}{ Kriteria } \\
\hline & & 1 & 2 & 3 & 4 & 5 & & & \\
\hline 1 & $\begin{array}{l}\text { Saya merasa terikat secara } \\
\text { emosional dengan } \\
\text { perusahaan. }\end{array}$ & 4 & 5 & 27 & 13 & 5 & 172 & 3,19 & $\begin{array}{l}\text { Cukup } \\
\text { tinggi }\end{array}$ \\
\hline 2 & $\begin{array}{l}\text { Saya merasa bangga } \\
\text { terhadap perusahaan } \\
\text { tempat ia bekerja. }\end{array}$ & 3 & 9 & 24 & 15 & 3 & 168 & 3,11 & $\begin{array}{l}\text { Cukup } \\
\text { tinggi }\end{array}$ \\
\hline 3 & $\begin{array}{l}\text { Saya merasa ikut memiliki } \\
\text { perusahaan. }\end{array}$ & 2 & 7 & 26 & 11 & 8 & 178 & 3,30 & $\begin{array}{l}\text { Cukup } \\
\text { tinggi }\end{array}$ \\
\hline 4 & $\begin{array}{l}\text { Saya merasa kehidupannya } \\
\text { akan terganggu apabila } \\
\text { meninggalkan perusahaan. }\end{array}$ & 2 & 8 & 26 & 11 & 7 & 175 & 3,24 & $\begin{array}{l}\text { Cukup } \\
\text { tinggi }\end{array}$ \\
\hline 5 & $\begin{array}{l}\text { Saya merasa sedikit } \\
\text { memiliki pilihan jika } \\
\text { meninggalkan perusahaan. }\end{array}$ & 1 & 9 & 30 & 9 & 5 & 170 & 3,15 & $\begin{array}{l}\text { Cukup } \\
\text { tinggi }\end{array}$ \\
\hline 6 & $\begin{array}{lr}\text { Saya merasa } & \text { bekerja pada } \\
\text { organisasi } & \text { tersebut } \\
\text { merupakan } & \text { kesempatan } \\
\text { yang terbaik. } & \end{array}$ & 2 & 11 & 24 & 15 & 2 & 166 & 3,07 & $\begin{array}{l}\text { Cukup } \\
\text { tinggi }\end{array}$ \\
\hline 7 & $\begin{array}{l}\text { Saya bersedia dilibatkan } \\
\text { dalam kegiatan kerja demi } \\
\text { kepentingan perusahaan. }\end{array}$ & 1 & 10 & 24 & 12 & 7 & 176 & 3,26 & $\begin{array}{l}\text { Cukup } \\
\text { tinggi }\end{array}$ \\
\hline 8 & $\begin{array}{l}\text { Saya berkeinginan untuk } \\
\text { menghabiskan sisa } \\
\text { karirnya pada perusahaan. }\end{array}$ & 2 & 10 & 30 & 5 & 7 & 167 & 3,09 & $\begin{array}{l}\text { Cukup } \\
\text { tinggi }\end{array}$ \\
\hline \multicolumn{7}{|c|}{ Rata-rata } & & 3,18 & $\begin{array}{c}\text { Cukup } \\
\text { tinggi }\end{array}$ \\
\hline
\end{tabular}

Sumber : Data diolah, 2019 
Variabel komitmen organisasional yang memiliki rata-rata terendah adalah pernyataan "Saya merasa bekerja pada organisasi tersebut merupakan kesempatan yang terbaik.", berarti secara umum mereka merasa bekerja pada organisasi tersebut belum merupakan kesempatan yang terbaik. Variabel komitmen organisasional yang memiliki rata-rata tertinggi adalah pernyataan "Saya merasa ikut memiliki perusahaan.”, berarti secara umum responden merasa ikut memiliki perusahaan.

Tabel 6.

Deskripsi Jawaban Responden terhadap Kepemimpinan transformasional

\begin{tabular}{|c|c|c|c|c|c|c|c|c|c|}
\hline \multirow[t]{2}{*}{ No } & \multirow[t]{2}{*}{ Pernyataan } & \multicolumn{5}{|c|}{$\begin{array}{c}\text { Proporsi Jawaban } \\
\text { Responden }\end{array}$} & \multirow[t]{2}{*}{ Jumlah } & \multirow{2}{*}{$\begin{array}{l}\text { Rata- } \\
\text { rata }\end{array}$} & \multirow[t]{2}{*}{ Kriteria } \\
\hline & & 1 & 2 & 3 & 4 & 5 & & & \\
\hline 1 & $\begin{array}{l}\text { Supervisor mampu } \\
\text { menyampaikan visi misi } \\
\text { perusahaan pada } \\
\text { bawahannya. }\end{array}$ & 4 & 4 & 27 & 13 & 6 & 175 & 3,24 & $\begin{array}{l}\text { Cukup } \\
\text { kuat }\end{array}$ \\
\hline 2 & $\begin{array}{l}\text { Supervisor membuat } \\
\text { bawahannya bangga } \\
\text { karena pendirian kuat } \\
\text { dalam memimpin }\end{array}$ & 3 & 8 & 23 & 18 & 2 & 170 & 3,15 & $\begin{array}{c}\text { Cukup } \\
\text { kuat }\end{array}$ \\
\hline 3 & $\begin{array}{l}\text { Supervisor memberikan } \\
\text { dorongan kepada } \\
\text { karyawan agar semangat } \\
\text { dalam bekerja }\end{array}$ & 4 & 5 & 26 & 11 & 8 & 176 & 3,26 & $\begin{array}{c}\text { Cukup } \\
\text { kuat }\end{array}$ \\
\hline 4 & $\begin{array}{l}\text { Supervisor merangsang } \\
\text { inovasi dan kreatifitas } \\
\text { bawahan dalam bekerja. }\end{array}$ & 3 & 7 & 27 & 10 & 7 & 173 & 3,20 & $\begin{array}{c}\text { Cukup } \\
\text { kuat }\end{array}$ \\
\hline 5 & $\begin{array}{l}\text { Supervisor mampu melatih } \\
\text { bawahannya }\end{array}$ & 5 & 4 & 31 & 9 & 5 & 167 & 3,09 & $\begin{array}{l}\text { Cukup } \\
\text { kuat }\end{array}$ \\
\hline 6 & $\begin{array}{l}\text { Supervisor mampu untuk } \\
\text { memperhatikan } \\
\text { kebututuhan bawahan. }\end{array}$ & 3 & 5 & 28 & 11 & 7 & 176 & 3,26 & $\begin{array}{c}\text { Cukup } \\
\text { kuat }\end{array}$ \\
\hline \multicolumn{8}{|c|}{ Rata-rata } & 3,20 & $\begin{array}{c}\text { Cukup } \\
\text { kuat }\end{array}$ \\
\hline
\end{tabular}

Sumber : Data diolah, 2019

Variabel kepemimpinan transformasional yang memiliki rata-rata terendah adalah pernyataan "supervisor mampu melatih bawahannya", berarti secara umum responden menganggap supervisor belum mampu melatih bawahannya. Variabel kepemimpinan transformasional yang memiliki rata-rata tertinggi adalah pernyataan "supervisor mampu memberikan dorongan kepada karyawan agar semangat dalam bekerja dan supervisor mampu untuk memperhatikan kebututuhan bawahan.", berarti secara umum supervisor mampu memberikan dorongan kepada karyawan agar semangat dalam bekerja dan supervisor mampu untuk memperhatikan kebututuhan bawahan.

Variabel kepuasan kerja yang memiliki rata-rata terendah adalah pernyataan "Saya merasa puas dengan pekerjaan yang saya milik dan Saya merasa puas memiliki rekan kerja yang mampu memubuat situasi kerja menyenangkan.", berarti 
secara umum responden menganggap belum merasa puas dengan pekerjaan yang saya milik dan belum merasa puas memiliki rekan kerja yang mampu memubuat situasi kerja menyenangkan. Variabel kepuasan kerja yang memiliki rata-rata tertinggi adalah pernyataan "Saya merasa puas dengan adanya kesempatan untuk mendapat promosi ke jabatan yang lebih tinggi", berarti secara umum responden merasa puas dengan adanya kesempatan untuk mendapat promosi ke jabatan yang lebih tinggi. Jawaban responden mengenai masing-masing pernyataan pada variabel komitmen organisasional, kepemimpinan transformasional dan kepuasan kerja diukur skala Likert, yang dapat dilihat secara rinci pada Tabel berikut:

Tabel 7.

Deskripsi Jawaban Responden terhadap Kepuasan kerja

\begin{tabular}{|c|c|c|c|c|c|c|c|c|c|}
\hline \multirow[t]{2}{*}{ No } & \multirow[t]{2}{*}{ Pernyataan } & \multicolumn{5}{|c|}{$\begin{array}{c}\text { Proporsi Jawaban } \\
\text { Responden }\end{array}$} & \multirow[t]{2}{*}{ Jumlah } & \multirow{2}{*}{$\begin{array}{l}\text { Rata- } \\
\text { rata }\end{array}$} & \multirow[t]{2}{*}{ Kriteria } \\
\hline & & 1 & 2 & 3 & 4 & 5 & & & \\
\hline 1 & $\begin{array}{l}\text { Saya puas dengan gaji } \\
\text { sesuai dengan kontribusi } \\
\text { yang saya berikan. }\end{array}$ & 0 & 11 & 27 & 10 & 6 & 173 & 3,20 & $\begin{array}{l}\text { Cukup } \\
\text { Baik }\end{array}$ \\
\hline 2 & $\begin{array}{l}\text { Saya puas dengan } \\
\text { pekerjaan saya. }\end{array}$ & 2 & 12 & 22 & 15 & 3 & 167 & 3,09 & $\begin{array}{l}\text { Cukup } \\
\text { Baik }\end{array}$ \\
\hline 3 & $\begin{array}{l}\text { Saya puas } \\
\text { kesempatan } \\
\text { jabatan. }\end{array}$ & 0 & 11 & 23 & 13 & 7 & 178 & 3,30 & $\begin{array}{l}\text { Cukup } \\
\text { Baik }\end{array}$ \\
\hline 4 & $\begin{array}{lr}\text { Saya puas } & \text { dengan } \\
\text { pengawasan } & \text { yang } \\
\text { diberikan atasan } & \end{array}$ & 1 & 11 & 29 & 7 & 6 & 168 & 3,11 & $\begin{array}{l}\text { Cukup } \\
\text { Baik }\end{array}$ \\
\hline 5 & $\begin{array}{lr}\text { Saya puas memiliki rekan } \\
\text { kerja yang memubuat } \\
\text { situasi } & \text { kerja } \\
\text { menyenangkan. } & \end{array}$ & 0 & 13 & 27 & 10 & 4 & 167 & 3,09 & $\begin{array}{l}\text { Cukup } \\
\text { Baik }\end{array}$ \\
\hline \multicolumn{8}{|c|}{ Rata-rata } & 3,16 & $\begin{array}{c}\text { Cukup } \\
\text { Baik }\end{array}$ \\
\hline
\end{tabular}

Pada penelitian ini pengujian normalitas dilakukan menggunakan analisis grafik histogram, Normal probability plot dan analisis statistik One-Sample Kolmogorov-Smirnov, yaitu dengan membandingkan Kolmogorov-Smirnov hitung dengan Kolmogorov-Smirnov. Adapun hasil uji One-Sample Kolmogorov-Smirnov dapat ditampilkan dalam Tabel 8. berikut:

Tabel 8.

Uji Normalitas (One-Sample Kolmogorov-Smirnov)

$\begin{array}{ll}\text { Persamaan } & \text { Kolmogorov-Smirnov Z } \\ \text { Substruktur 1 } & 0,117 \\ \text { Substruktur 2 } & 0,105\end{array}$

Sumber : Data diolah, 2019 
Berdasarkan uji normalitas dengan menggunakan One-Sample KolmogorovSmirnov Test yang ditampilkan pada Tabel 8. tersebut menunjukkan bahwa besarnya nilai Kolmogorov-Smirnov adalah sebesar 0,117 dan 0,105 sehingga dapat disimpulkan bahwa model memenuhi asumsi normalitas.

Uji multikolinearitas dilakukan untuk melihat apakah terdapat korelasi yang sempurna antar variabel bebas yang digunakan pada penelitian ini. Pengujian multikolinearitas dilakukan dengan menganalisis nilai tolerance dan nilai VIF. Adapun nilai tolerance dan nilai VIF ditunjukkan pada Tabel 9.

Berdasarkan Tabel 9. tersebut ditunjukkan bahwa tidak terdapat variabel bebas yang memiliki nilai tolerance kurang dari 0,10. Maka dari model regresi bebas dari gejala multikoleniaritas.

Tabel 9. Uji Multikolinieritas

\begin{tabular}{clcc}
\hline & & & \multicolumn{2}{c}{ Collinearity Statistics } \\
\cline { 3 - 4 } & Kodel & Tolerance & VIF \\
\hline \multirow{3}{*}{ Substruktur2 } & Transformasional & 0.381 & 2.626 \\
& Kepuasan Kerja & 0.381 & 2.626 \\
\hline
\end{tabular}

Sumber : Data diolah, 2019

Pengujian heteroskedastisitas diakukan melalui metode glesjer dan dengan grafik scatterplot. Metode glesjer meregresikan model regresi untuk mendapatkan nilai residualnya, kemudian nilai residual tersebut diabsolutkan dan dilakukan regresi dengan semua variabel independen. Bila terdapat variabel independen yang berpengaruh secara signifikan terhadap residual absolut maka terjadi heteroskedastisitas pada model regresi ini. Adapun hasil dari uji Hesteroskedastisitas ditunjukan pada Tabel 10 berikut:

Tabel 10.

Uji Heteroskedastisitas (Uji Glesjer)

\begin{tabular}{clrr}
\hline Persamaan & \multicolumn{1}{c}{ Model } & T & Sig. \\
\hline Substruktur1 & Kepemimpinan Transformasional & 1.105 & 0.190 \\
Substruktur 2 & Kepemimpinan Transformasional & 1.405 & 0.159 \\
& Kepuasan Kerja & -1.383 & 0.173 \\
\hline Sumber : Data diolah, 2019 & &
\end{tabular}

Berdasarkan Tabel 10. ditunjukkan bahwa masing-masing model memiliki nilai signifikansi lebih besar dari 5 persen, maka dari itu, penelitian ini bebas dari gejala heteroskedastisitas.

Tabel 11.

Hasil Analisis Jalur pada Struktur 1 


\begin{tabular}{|c|c|c|c|c|c|}
\hline \multirow{2}{*}{ Model } & \multicolumn{2}{|c|}{ Unstandardized Coefficients } & \multirow{2}{*}{$\begin{array}{c}\begin{array}{c}\text { Standardized } \\
\text { Coefficients }\end{array} \\
\text { Beta } \\
\end{array}$} & \multirow[t]{2}{*}{$\mathbf{T}$} & \multirow[t]{2}{*}{ Sig. } \\
\hline & B & Std. Error & & & \\
\hline (Constant) & 4.450 & 1.282 & & 3.472 & 0.001 \\
\hline $\begin{array}{l}\text { Kepemimpinan } \\
\text { Transformasional }\end{array}$ & 0.591 & 0.064 & 0.787 & 9.194 & 0.000 \\
\hline$: 0,619$ & & & & & \\
\hline
\end{tabular}

Pada penelitian ini digunakan teknik path analysis dalam melihat pengaruh hubungan kausalistik masing-masing variabel eksogen yang terdiri dari Kepemimpinan Transformasional terhadap variabel endogen yang terdiri dari kepuasan kerja dan komitmen organisasi.

Berdasarkan hasil analisis jalur substruktur 1 maka dapat dibuat persamaan struktural sebagai berikut:

$\mathrm{M}=\beta 1 \mathrm{X}+\mathrm{e} 1$

$\mathrm{M}=0,787 \mathrm{X}+\mathrm{e}_{1}$

Persamaan struktural tersebut dapat diartikan yaitu variabel kepemimpinan transformasional memiliki koefisien sebesar 0,787 berarti kepemimpinan transformasional memiliki pengaruh positif terhadap kepuasan kerja, ini diartikan apabila kepemimpinan transformasional meningkat maka kepuasan kerja akan meningkat sebesar 0,787 .

Tabel 12.

Hasil Analisis Jalur pada Struktur 2

\begin{tabular}{|c|c|c|c|c|c|}
\hline \multirow{2}{*}{ Model } & \multicolumn{2}{|c|}{$\begin{array}{l}\text { Unstandardized } \\
\text { Coefficients }\end{array}$} & \multirow{2}{*}{$\begin{array}{c}\text { Standardized } \\
\text { Coefficients }\end{array}$} & \multirow[t]{2}{*}{$\mathbf{T}$} & \multirow[t]{2}{*}{ Sig. } \\
\hline & B & Std. Error & & & \\
\hline (Constant) & 2.134 & 1.380 & & 1.547 & 0.128 \\
\hline $\begin{array}{l}\text { Kepemimpinan } \\
\text { Transformasional }\end{array}$ & 0.800 & 0.101 & 0.664 & 7.921 & 0.000 \\
\hline Kepuasan kerja & 0.501 & 0.134 & 0.312 & 3.724 & 0.000 \\
\hline$: 0.864$ & & & & & \\
\hline
\end{tabular}

Sumber : Data diolah, 2019

Berdasarkan hasil analisis jalur substruktur 2 seperti yang disajikan pada Tabel 14, maka dapat dibuat persamaan struktural sebagai berikut :

$\mathrm{Y}=\beta 2 \mathrm{X}+\beta 3 \mathrm{M}+\mathrm{e}_{2}$

$Y=0,664 X+0,312 \mathrm{M}$

Variabel kepemimpinan transformasional memiliki koefisien sebesar 0,664 berarti kepemimpinan transformasional memiliki pengaruh positif terhadap komitmen organisasi, ini diartikan apabila kepemimpinan transformasional 
meningkat maka komitmen organisasi akan meningkat sebesar 0,664. Variabel kepuasan kerja memiliki koefisien sebesar 0,312 berarti kepuasan kerja memiliki pengaruh positif terhadap komitmen organisasi ini diartikan apabila kepuasan kerja meningkat maka komitmen organisasi akan meningkat sebesar 0,312.

Pada perhitungan nilai koefisien determinasi total didapatkan sebesar 0,995, maka kesimpulannya adalah 99,5 persen variabel komitmen organisasi Pada karyawan KutaBex Beach Front Hotel, Bali dipengaruhi oleh kepemimpinan transformasional, dan kepuasan kerja, sedangkan sisanya 0,5\% dipengaruhi oleh faktor lain yang tidak dimasukkan dalam model penelitian atau diluar model penelitian. Kepemimpinan transformasional memiliki nilai Beta sebesar 0,787 dan nilai Sig. sebesar 0,000, maka dapat dikatakan $\mathrm{H}_{1}$ diterima karena nilai Sig. $0,000<0,05$. Kesimpulannya adalah bahwa kepemimpinan transformasional memiliki pengaruh positif dan signifikan secara parsial terhadap kepuasan kerja dengan kata lain semakin meningkat kepemimpinan transformasional pada KutaBex Beach Front Hotel, Bali, maka semakin meningkat kepuasan kerja pada karyawan kutabex beach front hotel, bali sehingga hipotesis pertama diterima.

Kepemimpinan transformasional memiliki nilai Beta sebesar 0,664 dan nilai Sig. sebesar 0,000, maka dapat dikatakan $\mathrm{H}_{2}$ diterima karena nilai Sig. $0,000<0,05$. Kesimpulannya adalah kepemimpinan transformasional berpengaruh positif dan signifikan secara parsial terhadap komitmen organisasi dengan kata lain semakin meningkat kepemimpinan transformasional maka komitmen organisasi pada karyawan Kutabex Beach Front Hotel, bali akan semakin meningkat. Sehingga hipotesis kedua diterima.

Kepuasan kerja memiliki nilai Beta sebesar 0,312 dan nilai Sig. sebesar 0.000, maka dapat dikatakan $\mathrm{H}_{3}$ diterima karena nilai Sig. 0.000< 0,05. Kesimpulannya adalah bahwa Kepuasan kerja memiliki pengaruh positif dan signifikan secara parsial terhadap komitmen organisasi, dengan kata lain apabila kepuasan kerja meningkat maka komitmen organisasi Pada karyawan KutaBex Beach Front Hotel, Bali. akan semakin meningkat. Sehingga hipotesis ketiga diterima.

Berdasarkan perhitungan pengaruh secara langsung, pengaruh tidak langsung dan pengaruh total dari masing-masing persamaan struktural yang akan disajikan dalam Tabel 13. berikut:

Tabel 13.

Pengaruh Langsung dan Pengaruh Tidak Langsung

\begin{tabular}{lccc}
\hline \multicolumn{1}{c}{ Pengaruh variabel } & $\begin{array}{c}\text { Pengaruh } \\
\text { langsung }\end{array}$ & $\begin{array}{c}\text { Pengaruh tidak } \\
\text { langsung melalui } \mathbf{M}\end{array}$ & Pengaruh Total \\
\hline $\mathrm{X} \rightarrow \mathrm{M}$ & 0,787 & & 0,787 \\
$\mathrm{M} \rightarrow \mathrm{Y}$ & 0,312 & & 0,312 \\
$\mathrm{X} \rightarrow \mathrm{Y}$ & 0,664 & 0,246 & 0,910 \\
\hline
\end{tabular}

Sumber : Data diolah, 2019

Penelitian yang dilakukan pada karyawan KutaBex Beach Front Hotel, Bali tentang pengaruh kepemimpinan transformasional terhadap kepuasan kerja, maka didapatkan hasil kepemimpinan transformasional memiliki pengaruh langsung 
terhadap kepuasan kerja dengan persentase sebesar 0,787 atau $78,7 \%$. Penelitian yang dilakukan pada karyawan KutaBex Beach Front Hotel, Bali tentang pengaruh kepuasan kerja terhadap komitmen organisasi, maka didapatkan hasil kepuasan kerja memiliki pengaruh langsung terhadap komitmen organisasi dengan persentase sebesar 0,312 atau $31,2 \%$. Penelitian yang dilakukan pada karyawan KutaBex Beach Front Hotel, Bali tentang pengaruh kepemimpinan transformasional terhadap komitmen organisasi, maka didapatkan hasil kepemimpinan transformasional memiliki pengaruh langsung terhadap komitmen organisasi dengan persentase sebesar 0,664 atau 66,4\%.

Penelitian yang dilakukan Pada karyawan KutaBex Beach Front Hotel, Bali tentang peran kepuasan kerja dalam memediasi pengaruh Kepemimpinan transformasional terhadap komitmen organisasi, maka didapatkan hasil bahwa kepemimpinan transformasional memiliki pengaruh langsung dan tidak langsung melalui kepuasan kerja terhadap komitmen organisasi dengan nilai koefisien masing-masing sebesar 0,664 dan 0,246, sehingga besaran pengaruh totalnya adalah 0,910 atau $91 \%$.

Berdasarkan hasil Uji Sobel menunjukkan bahwa hasil tabulasi $\mathrm{Z}=$ 2,280>1,96 yang berarti variabel kepemimpinan transformasional berpengaruh positif dan signifikan terhadap komitmen organisasi pada karyawan KutaBex Beach Front Hotel, Bali dengan mediasi kepuasan kerja, sehingga kepuasan kerja merupakan variabel mediasi pengaruh antara kepemimpinan transformasional terhadap komitmen organisasi pada karyawan KutaBex Beach Front Hotel, Bali, sehingga hipotesis keempat diterima.

Hasil hipotesis dalam penelitian ini menunjukkan bahwa kepemimpinan transformasional memiliki pengaruh positif dan signifikan terhadap kepuasan kerja, dengan kata lain semakin meningkat kepemimpinan transformasional pada KutaBex Beach Front Hotel, Bali, maka semakin tinggi tingkat kepuasan kerja pada karyawan KutaBex Beach Front Hotel, Bali. Sehingga hipotesis pertama diterima. kepemimpinan adalah sekumpulan ciri yang digunakan pimpinan untuk memengaruhi bawahan agar sasaran organisasi tercapai atau dapat pula dikatakan bahwa gaya kepemimpinan adalah pola perilaku dan strategi yang disukai dan sering diterapkan oleh seorang pemimpin. Terdapat beberapa penelitian mengenai pengaruh kepemimpinan transformasional terhadap kepuasan kerja

Hal ini sejalan dengan hasil penelitian yang dilakukan oleh Babalola (2016) bahwa kinerja pengawas dalam hal kepemimpinan transformasional dapat memiliki dampak signifikan positif pada bawahan tingkat kepuasan kerja. Athanasios \& Belias (2015) juga mengatakan bahwa kepemimpinan transformasional berpengaruh positif terhadap kepuasan kerja. Idrus et al. (2016) menyatakan ada hubungan yang positif dan signifikan antara gaya kepemimpinan transformasional terhadap kepuasann kerja karyawan. Li et al. (2019) mengatakan bahwa organisasi perlu memiliki pemimpin tipe transformasional untuk memberikan tim yang efektif 
dalam bekerja untuk meningkatkan kepuasan kerja. Penelitian Eliyana et al. (2019) menyimpulkan bahwa kepemimpinan transformasional secara parsial merupakan variabel yang mampu meningkatkan kepuasan kerja karyawan.

Hasil hipotesis dalam penelitian ini menunjukkan bahwa kepemimpinan transformasional berpengaruh positif dan signifikan terhadap komitmen organisasi dengan kata lain semakin meningkat kepemimpinan transformasional maka komitmen organisasi pada karyawan KutaBex Beach Front Hotel, Bali akan semakin meningkat. Sehingga hipotesis kedua diterima. Kepemimpinan transformasional cenderung meningkatkan harga diri dan nilai kerja pengikut dengan menjadi anggota dari pemimpin dimana pengikut menerima dukungan yang lebih baik dan bangga menjadi anggota dari pemimpin sehingga dapat meningkatkan komitmen mereka terhadap organisasi. Hal ini sejalan dengan hasil penelitian yang dilakukan oleh Widjaja et al. (2016), Gulluce et al. (2016), Njoroge et al. (2015), Supit (2016) dan Jain \& Duggal (2016) juga menemukan bahwa kepemimpinan transformasional berpengaruh positif terhadap komitmen organisasional karyawan.

Hasil hipotesis dalam penelitian ini menunjukkan bahwa kepuasan kerja memiliki pengaruh positif dan signifikan terhadap komitmen organisasi, dengan kata lain apabila kepuasan kerja meningkat maka komitmen organisasi pada karyawan KutaBex Beach Front Hotel, Bali. akan semakin meningkat. Sehingga hipotesis ketiga diterima. Kepuasan kerja merupakan hal penting yang dimiliki individu di dalam bekerja, dimana setiap individu pekerja memiliki karakteristik yang berbeda - beda, maka tingkat kepuasan kerjanya pun berbeda - beda pula. Hasil penelitian ini sesuai dengan penelitian yang dilakukan oleh Imam et al. (2015), Wardhani et al. (2015), Tentama \& Pranungsari (2016), Karakus et al. (2015) dan Shurbagi (2015) mendapatkan hasil bahwasannya kepuasan kerja mempunyai pengaruh positif juga signifikan terhadap komitmen organisasional

Hasil hipotesis dalam penelitian ini menunjukkan bahwa kepemimpinan transformasional berpengaruh positif dan signifikan terhadap komitmen organisasi pada karyawan KutaBex Beach Front Hotel, Bali dengan mediasi Kepuasan kerja, sehingga kepuasan kerja merupakan variabel mediasi pengaruh antara kepemimpinan transformasional terhadap komitmen organisasi pada karyawan KutaBex Beach Front Hotel, Bali, Sehingga hipotesis keempat diterima. Hasil penelitian ini sejalan dengan Akbar et al. (2016) meneliti hubungan antara variabel kepuasan kerja dan komitmen organisasional, yang membuktikan. Hubungan positif moderat signifikan juga ditemukan antara aspek kepuasan kerja, faktor demografi, dan komitmen organisasional. Zulkarnaen \& Sudarma (2018) yang menyatakan bahwa kepemimpinan yang bergaya transformasional memiliki pengaruh positif terhadap kepuasan kerja pegawai. Menurut Kesuma \& Supartha (2016) menyatakan bahwa kepuasan kerja memediasi kepemimpinan trasfomasional terhadap komitmen organisasional.

Hasil penelitian ini mendukung teori yang digunakan sebagai dasar dalam pembuatan hipotesis bahwa kepemimpinan tranformasional mempengaruhi 
komitmen organisasional, selain itu peran kepuasan kerja mampu memediasi kepemimpinan tranformasional terhadap komitmen organisasional. Ketika karyawan merasa mendapat dorongan dan motivasi dari atasannya dan disertai dengan kepuasan kerja yang tinggi, maka akan dapat meningkatkan komitmen organisasional. Hal ini menunjukan bahwa hasil penelitian memperkuat teori yang digunakan. Teori yang digunakan dalam penelitian ini adalah social exchange theory atau teori pertukaran sosial.

Implikasi hasil penelitian ini memfokuskan pada kegunaan dan manfaat dari hasil penelitian untuk meningkatkan komitmen organisasional melalui kepemimpinan transformasional dan kepuasan kerja. Implikasi yang pertama hasil bahwa KutaBex Beach Front Hotel,Bali menerapkan gaya kepemimpinan transformasional dengan baik, dimana pemimpin mampu menyampaikan visi perusahaan pada bawahannya dan pemimpin mampu untuk memperhatikan kebutuhan bawahan sehingga karyawan mampu meningkatkan kontribusi dalam kesuksesan perusahaan. Implikasi yang kedua yaitu diperoleh hasil bahwa tingginya kepuasan kerja KutaBex Beach Front Hotel, Bali dimana karyawan merasa puas terhadap perusahaan dan tempatnya bekerja dan karyawan merasa bekerja pada perusahaan dan merasa diperhatikan oleh perusahaan maka karyawan akan puas dan melakukan pekerjaan sesuai dengan tujuan yang ingin dicapai perusahaan.

Penelitian ini dilakukan hanya sebatas pada ruang lingkup KutaBex Beach Front Hotel, Bali sehingga hasil penelitian ini tidak dapat digunakan pada perusahaan lain dalam sektor perhotelan sejenis ataupun perusahaan pada sektor lainnya. Faktor-faktor yang mempengaruhi komitmen organisasional dalam penelitian ini adalah kepemimpinan transformasional dan kepuasan kerja, sedangkan masih banyak faktor lain yang dapat mempengaruhi.

\section{SIMPULAN}

Kepemimpinan transformasional berpengaruh positif dan signifikan terhadap komitmen organisasi pada karyawan KutaBex Beach Front Hotel, Bali. Hal ini menunjukan bahwa semakin kuat kepemimpinan transformasional maka komitmen organisasi karyawan akan semakin meningkat. Kepemimpinan transformasional berpengaruh positif dan signifikan terhadap kepuasan kerja pada karyawan KutaBex Beach Front Hotel, Bali. Hal ini menunjukan bahwa semakin kuat kepemimpinan transformasional maka karyawan akan semakin puas terhadap pekerjaannya.

Kepuasan kerja berpengaruh positif dan signifikan terhadap komitmen organisasi pada karyawan KutaBex Beach Front Hotel, Bali. Hal ini menunjukan bahwa semakin puas karyawan dalam perusahaan maka komitmen organisasional karyawan akan semakin meningkat. Kepuasan kerja merupakan variabel mediasi 
pengaruh antara kepemimpinan transformasional terhadap komitmen organisasi pada karyawan KutaBex Beach Front Hotel, Bali. Hal ini menunjukan bahwa kepuasan kerja mampu memediasi kepemimpinan transformasional terhadap komitmen organisasional pada KutaBex Beach Front hotel Bali.

Pihak perusahaan sebaiknya lebih memperhatikan setiap keluhan yang dirasakan karyawan dengan cara memberikan dukungan dan motivasi kepada karyawan sehingga akan menimbulkan rasa kebermaknaan serta perasaan senang dan karyawan merasa dianggap penting oleh perusahaan. Pihak perusahaan sebaiknya memperhatikan tunjangan-tunjangan yang di berikan seperti asuransi, insentif, dan fasilitas lainnya sehingga kepuasan kerja akan terus berada pada titik terbaik dimana secara langsung akan mempengaruhi kinerja dan komitmen karyawan pada perusahaan. Upaya meningkatkan komitmen organisasional perusahaan harus mampu membuat karyawannya berkeinginan untuk menghabiskan sisa karir pada perusahaan karena karyawan merupakan aset yang paling penting dalam menajalankan suatu perusahaan.

\section{REFERENSI}

Akbar, F. U., Hamid, J., \& Djudi, M. (2016). Pengaruh Kepuasan Kerja Terhadap Komitmen Organisasional Dan Kinerja Karyawan ( Studi pada Karyawan Tetap PG Kebon Agung Malang ). Jurnal Administrasi Bisnis (JAB), 38(2), 79-88.

Athanasios, K., \& Belias, D. (2015). Leadership And Job Satisfaction- A Review. European Scientific Journal, 10(8), 287-295.

Babalola, S. S. (2016). The effect of leadership style, job satisfaction and employeesupervisor relationship on job performance and organizational commitment. Journal of Applied Business Research, 32(3), 935-946. https://doi.org/10.19030/jabr.v32i3.9667

Bhaskara, I. G., \& Subudi, M. (2019). Pengaruh Kepemimpinan Transformasional Terhadap Komitmen Organisasional Melalui Mediasi Kepuasan Kerja. EJurnal Manajemen Unud, 8(3), 1727 - 1754.

Chan, S. C. H., \& Mak, W. M. (2015). Transformational leadership, pride in being a follower of the leader and organizational commitment. Leadership \& Organization Development Journal, 35(8), 674-690.

Eliyana, A., Ma'arif, S., \& Muzakki. (2019). Job satisfaction and organizational commitment effect in the transformational leadership towards employee performance. European Research on Management and Business Economics, 25(3), 144-150. https://doi.org/https://doi.org/10.1016/j.iedeen.2019.05.001

Gulluce, A. Ç., Kaygin, E., Kafadar, S. B., \& Atay, M. (2016). The Relationship between Transformational Leadership and Organizational Commitment: A 
Study on the Bank Employees. Journal of Service Science and Management, 09(03), 263-275. https://doi.org/10.4236/jssm.2016.93033

Idrus, M. I., Hamzah, D., Maupa, H., \& Muis, M. (2016). Transformational Leadership Style Effects on the Job Satisfaction of Government Employees. International Journal of Scientific and Research Publications, 6(4), 682-686.

Imam, A., Raza, A., \& Ahmed, M. (2015). Impact Of Job Satisfaction On Organizational Commitment In Bank Sector Employees Of Pakistan. Sci.Int(Lahore), 26(1), 419-423.

Jain, P., \& Duggal, T. (2016). The Influence of Transformational Leadership and Emotional Intelligence on Organizational Commitment. Journal of Commerce \& Management Thought, 7(3), 586-598.

Karakus, M., Mehmet, U., \& Mustafa., T. (2015). Two alternative models on the relationships between organizational justice, organizational commitment, burnout, and job satisfaction of education supervisors. KEDI Journal of Educational Policy, 11(1), 69 - 94.

Kesuma, I. G. A. W., \& Supartha, I. W. G. (2016). Pengaruh Kepemimpinan Transformasional Terhadap Komitmen Organisasional Dengan Mediasi Organizational Citizenship Behavior Dan Kepuasan Kerja. E-Jurnal Manajemen Unud, 5(6), 3677-3705.

Li, H., Sajjad, N., Wang, Q., Ali, A. M., Khaqan, Z., \& Amina, S. (2019). Influence of transformational leadership on employees' innovative work behavior in sustainable organizations: Test of mediation and moderation processes. $\begin{array}{llll}\text { Sustainability } \quad \text { (Switzerland), } & 11(6), 21 .\end{array}$ https://doi.org/10.3390/su11061594

Mighfar, S. (2015). Social Exchange Theory. Al-Hal, 9(2), 261-286.

Njoroge, D., Gachunga, H., \& Kihoro, J. (2015). Transformasional Leadership Style and Organizational Commitment: The Moderating Effect Of Employee Participation. The Strategic Journal of Business \& Change Management, 2(9), 94-107.

Putra, I. G. A. G. E. M., \& Wibawa, I. M. A. (2015). Pengaruh Kepuasan Kerja terhadap Turnover Intention dengan Komitmen organisasional sebagai variabel Intervening pada PT. Autobagus Rent Car Bali. E-Jurnal Manajemen Unud, 4(4), 1100-1118.

Shah, F. T., Idrees, F., Imam, A., Khan, T. A., \& Mariyam, A. (2015). Impact of 
Job Satisfaction on Organizational Commitment in IT Sector Employees of Pakistan. Journal of Applied Environmental and Biological Sciences, 4(8), 190-197.

Shurbagi, A. M. A. (2015). The Relationship Between Transformational Leadership Style Job Satisfaction and the Effect of Organizational Commitment. Journal International Business, 7(11), 126 - 138.

Supit, I. Y. I. (2016). Pengaruh Gaya Kepemimpinan Transformasional Terhadap Komitmen Organisasional dan Organizational Citizenship Behavior yang Dimediasi Oleh Kepuasan Kerja. Jurnal Riset Bisnis Dan Manajemen, 4(3), 351-368.

Suryaningsih, T., Cahyoadi, B., \& Ilham Madhuri, N. (2017). Pengaruh Kepemimpinan Transformasional Terhadap Komitmen Organisasi Sebagai Upaya Peningkatan Keunggulan Bersaing Salesman Sepeda Motor Di Wilayah Kabupaten Tulungagung. Abdimas, 1(10), 1-13. https://doi.org/10.31227/osf.io/xvd72

Tentama, \& Pranungsari. (2016). The Roles of Teachers' Work Motivation and Teachers' Job Satisfaction in the Organizational Commitment in Extraordinary Schools. International Journal of Evaluation and Research in Education (IJERE), 5(1), 39-45.

Tjahjono, H. K., Prasetyo, F., \& Palupi, M. (2018). Kepemimpinan Transformasional Pada Organizational Citizenship Behavior Dan Komitmen Afektif. Jurnal Manajemen Dan Pemasaran Jasa, 11(2), 217. https://doi.org/10.25105/jmpj.v11i2.2771

Wardhani, W. K., Susilo, H., \& Iqbal, M. (2015). Pengaruh Motivasi Kerja Terhadap Komitmen Organisasional dengan kepuasan kerja sebagai variabel intervening. Jurnal Administrasi Bisnis (JAB), 2(1), 1-10.

Widjaja, D. C., Gunawan, M., \& Nathania, F. (2016). Pengaruh Kepemimpinan Transformasional Terhadap Komitmen Organisasi Melalui Kepuasan Kerja Di Labore Coffee \& Eatery Malang. Jurnal Hospitality Dan Manajemen Jasa, 4(2), 474-483. https://doi.org/10.1017/CBO9781107415324.004

Zulkarnaen, \& Sudarma, I. N. (2018). Pengaruh Gaya Kepemimpinan Transformasional Dan Kompensasi Terhadap Kepuasan Kerja Karyawan Restoran Warung Taulan Badung. E-Jurnal Manajemen Unud, 7(1), 332359. https://doi.org/https://doi.org/10.24843/EJMUNUD.2018.v7.i01.p13 ISSN 